\title{
Assessment of Heavy Metals and Microbial Pollution of Lettuce (Lactuca sativa) Cultivated in Two Sites (Paspanga and Tanghin) of Ouagadougou, Burkina Faso
}

\author{
Marius Kounbèsiounè Somda1,2*, Saran Samake1,3, Donatien Kabore4, Mahamadi Nikiema1, \\ Iliassou Mogmenga1, Yerobessor Dabire ${ }^{1}$, Assietta Ouattara ${ }^{1}$, Ibrahim Keita ${ }^{1,3}$, \\ Henriette B. Mihin², Agbémébia Yawovi Akakpo²,5, Alfred S. Traore²
}

\begin{abstract}
${ }^{1}$ Laboratory of Microbiology and Microbial Biotechnology, Research Center in Biological Food and Nutrition Sciences (CRSBAN), Department of Biochemistry and Microbiology, University Ouagal Pr Joseph KI-ZERBO, Ouagadougou, Burkina Faso ${ }^{2}$ Laboratory of Food Technology, Department of Biochemistry and Microbiology, University Ouaga 1 Pr Joseph KI-ZERBO, Ouagadougou, Burkina Faso

${ }^{3}$ Laboratory of Applied Molecular Biology (LBMA), Faculty of Technics and Sciences, University of Sciences, Technics and Technologies of Bamako, Bamako, Mali

${ }^{4}$ Department of Food Technology, National Center of Scientific and Technological Research, Ouagadougou, Burkina Faso ${ }^{5}$ Laboratoire of Quality Control and Normalisation (LCQN), Institut of Agronomic Research of Togo, Lome, Togo

Email: *sokmarius@gmail.com
\end{abstract}

How to cite this paper: Somda, M.K., Samake, S., Kabore, D., Nikiema, M., Mogmenga, I., Dabire, Y., Ouattara, A., Keita, I., Mihin, H.B., Akakpo, A.Y. and Traore, A.S. (2019) Assessment of Heavy Metals and Microbial Pollution of Lettuce (Lactuca sativa) Cultivated in Two Sites (Paspanga and Tanghin) of Ouagadougou, Burkina Faso. Journal of Environmental Protection, 10, 454-471.

https://doi.org/10.4236/jep.2019.103026

Received: February 1, 2019

Accepted: March 23, 2019

Published: March 26, 2019

Copyright $\odot 2019$ by author(s) and Scientific Research Publishing Inc. This work is licensed under the Creative Commons Attribution International License (CC BY 4.0).

http://creativecommons.org/licenses/by/4.0/

\begin{abstract}
Environmental pollution can have detrimental effects on crop yield and its consumers. The current study was designed to investigate the potential human health risks associated with the consumption of lettuce crop contaminated with toxic heavy metals and microbiological status. Irrigated water, soil and lettuce were analyzed by AAS technics for heavy metals including $\mathrm{Cd}, \mathrm{Cr}, \mathrm{Cu}, \mathrm{Mn}, \mathrm{Ni}, \mathrm{Pb}$ and $\mathrm{Zn}$. Transfer factor $(T F)$, daily intake of metals $(D I M)$ and health risk index $(H R I)$ were also calculated. Microbial analysis was carried out for the presence foodborne pathogens. The results showed that the heavy metals contents were higher in the soil than wastewater and the vegetables. Heavy metals ranged $\left(\mathrm{mg} \cdot \mathrm{Kg}^{-1}\right)$ for $\mathrm{Cd}(1.27$ to 2.93$), \mathrm{Cr}$ (7.28 to 7.38), $\mathrm{Cu}$ (0.91 to 1.70$), \mathrm{Mn}$ (0.29 to 6.60$), \mathrm{Ni}$ (1.74 to 2.16$), \mathrm{Pb}$ (1.32 to 1.69 ), $\mathrm{Zn}$ (3.08 to 3.79); and were higher than the WHO maximum limit permissible $(\mathrm{ML})$ in vegetables. $H R I<1$ indicates minimal risk. $T F$ values designated an enhanced bio-contamination. Microbial numeration revealed the presence of spoiler and pathogenic microorganisms. The lettuce tested was not safe for human use, especially for direct consumption by human beings.
\end{abstract}




\section{Keywords}

Heavy Metal, Microorganisms, Pollution, Lactuca sativa, Risk Assessment, Burkina Faso

\section{Introduction}

Heavy metal contamination of vegetables cannot be underestimated as these foodstuffs are important components of human diet. Vegetables are rich sources of vitamins, minerals, and fibers, and also have beneficial antioxidative effects. However, intake of heavy metal-contaminated vegetables may pose a risk to the human health. Heavy metal contamination of the food items is one of the most important aspects of food quality assurance [1] [2] [3]. Rapid and unorganized urban and industrial developments have contributed to the elevated levels of heavy metals in the urban environment of developing countries such as Egypt [2] Iran [4], China [5] and India [1] [6].

In sub-Saharan Africa like other developing countries, the urban and out-of-town agriculture is an income source of many households. It contributes to the reduction of poverty, of unemployment and contributes to the food security. In Burkina, agriculture is the main source of income, and occupies $80 \%$ of population and contributes to $33 \%$ of gross national proceeds. The total market production in 2008 is valued to 747,488 tons [7].

However, agricultural activities are made around dams and restraints of water. The streaming water drained various organic and inorganic matters of urban environment in dams which could cause more pollution. In spite of it, this water serves for many uses (cleaning of vehicles, laundry, drink for animals, irrigation etc.) could be polluted [8]. The quantity of water used for irrigation is valued to 323 million $\mathrm{m}^{3}$ per year and represents $84 \%$ demand according department environment of Burkina [8].

Linked with environmental pollution, water pollution is also a problem of worldwide concern and ground water is extremely polluted due to unplanned disposal of untreated domestic sewage and industrial effluents into watercourses [9].

Sanitary and environmental risks are also due to practice of agriculture in urban environment by using of agricultural inputs as pesticides, nitrogen, phosphor, and raw organic matter containing undesirable residues as traces elements [10]. Heavy metals get accumulated with time in soils and plants due to waste water irrigation and absorbed minerals settle in edible tissue of the vegetables [11]. Heavy metals are potentially toxic for plants: phytotoxicity results in chlorosis, weak plant growth, yield depression and may even be accompanied by reduced nutrient uptake, disorders in plant metabolism and in leguminous plants, and reduced ability to fix molecular nitrogen [12] [13].

Heavy metals uptake by crops growing in contaminated soils is a potential hazard to human health because of transmission in the food chain [14] [15]. Re- 
cent reports indicated that heavy metals take driver's seat among the chief contaminants of leafy vegetables.

Trace metals may enter humans' through direct ingestion of soil, inhalation of dust and consumption of plants grown in metal-contaminated soil [16] [17]. Hazardous metal intake via food chain by humans has been reported in many countries [18]. Trace metal contamination of vegetables must be of great concern to scientist because of the health threat hazardous metals pose to humans and other living organisms. The concentrations of trace metals in most of these vegetables sold in the markets are unknown as much research had not been carried out.

The elements metallic traces are the third source of risk for the human and animal food after the mycotoxines and the micro-organisms [19]. The pollution of vegetables throughout trace elements is raised-up and risks on consumers health that ingest them through by food chain are enormous [20] [21].

Studies concern impact associated to illnesses diarrheic due to consumption of contaminated vegetables are more and more realized. Most studies have investigated the sanitary risk of vegetables associate to several sources of contamination [22].

Wastewater irrigation poses several threats to the environment through contamination by nutrients, heavy metals, salts, and nitrates [23]. It also poses a number of potential risks to human health via the consumption of or exposure to pathogenic microorganisms, heavy metals or harmful organic chemicals [24]. Effective wastewater treatment can reduce pathogen levels, but in most developing countries it is not an option for the municipal authorities due to the high costs involved [25].

Vegetables found in Ouagadougou are lettuce, cucumber, aubergine, carrot, tomato, onion, cabbage etc. are commonly grown in peri-urban areas and irrigated by water of dams.

Therefore, wastewater application on agricultural lands and their heavy metal accumulation by vegetables at Ouagadougou, is a cause of serious concern due to the potential public health impacts. It is often argued that heavy metals in sludge, when applied to soils, may enter in the food chain through plants or animals, contaminate surface and ground water, and thus cause health hazards [26] [27].

In Burkina Faso and particularly at Ouagadougou, lettuce is cultivated on a commercial scale using waste water for irrigation, but there is no information on the level of heavy metals and microbial contain in soils and vegetables produced.

This study was mainly investigated to evaluate the microbial load and the concentration of accumulated trace elements by lettuce irrigated with wastewater of dams.

\section{Material and Methods}

\subsection{Study Area}

Two main zones were selected on the basis of ground water and urban drains water irrigation. GPS Garmin eTrex Vista was used to registrate GPS coordi- 
nates of study sites at Ouagadougou. The site of Tanghin was located from north $12^{\circ} 23.577^{\prime}$ to East $001^{\circ} 32.274^{\prime}$ Latitude. The coordinates of Paspanga site were from north $12^{\circ} 23.137^{\prime}$ to East $001^{\circ} 30.830^{\prime}$.

\subsection{Collection of Samples}

\section{Soil sampling}

Surface $(0-30 \mathrm{~cm})$ complex soil samples were collected from two sites (Tanghin and Paspanga) for chemical soil analysis. The complex sample was collected from different locations at the same time 6.00 am (October, 2018). All the samples were completely mixed together to form a representative surface sample for analysis. The temperature of study site was ranged from $24.0^{\circ} \mathrm{C}$ to $36.5^{\circ} \mathrm{C}$ and $24.2^{\circ} \mathrm{C}$ to $36.6^{\circ} \mathrm{C}$ respectively for Tanghin and Paspanga.

\section{Vegetable and wastewater sampling}

Vegetable samples (roots and leaves of lettuce), and Low Groundwater (wastewater) were collected from two sites (Tanghin and Paspanga) of production. The samples were homogenized to obtain representative samples and were properly labelled and transported to the laboratory in clean polythene bags for analysis.

\section{Processing of samples}

The collected samples were cleaned to remove the dust particles. A part of soil and sliced vegetable samples were dried in an oven at $105^{\circ} \mathrm{C}$ for $24 \mathrm{~h}$ until they were brittle and crisp [28], after drying the samples were grinded into a fine powder using a commercial blender and stored in polyethylene bags, until used for acid digestion [29]. The untreated parts of soil, vegetable and wastewaster samples were used directly for microbial analysis.

\subsection{Acid Digestion and Metals Determination of Samples}

Tri-acid mixture $\left(15 \mathrm{ml}, 70 \%\right.$ high purity $\mathrm{HNO}_{3}, 65 \% \mathrm{HClO}_{4}$ and $70 \% \mathrm{H}_{2} \mathrm{SO}_{4}$; 5:1:1) was added to the beaker containing $1 \mathrm{~g}$ dry vegetable sample [29]. The mixture was then digested at $80^{\circ} \mathrm{C}$ till the transparent solution was achieved.

After cooling, the digested samples were filtered using Whatman No. 42 filter paper and the filtrate was diluted to $50 \mathrm{ml}$ with deionised water. Determination of the heavy metals such as, $\mathrm{Cd}, \mathrm{Cr}, \mathrm{Cu}, \mathrm{Mn}, \mathrm{Ni}, \mathrm{Pb}$ and $\mathrm{Zn}$ in the filtrate of vegetables and atmospheric deposits was achieved by atomic absorption spectrophotometer (Shimadzu Model 6800 with graphite furnace Model GFA 7000). Thus wastewater parameters were analyzed according to the calibration methods used by the American Public Health Association for water and wastewater Analysis [30].

\subsection{Translocation Factor Calculation}

Transfer factor is the ratio of the concentration of heavy metals in a plant to the concentration of heavy metals in soil. The transfer factors $(T F)$ for each heavy metal was computed based on the method described [31] [32]. The $T F$ value for 
the selected heavy metals was calculated according to the following equation:

$$
T F=\left[P_{s}\left(\mathrm{mg} \cdot \mathrm{kg}^{-1} \text { dry weight }\right)\right] /\left[S_{t}\left(\mathrm{mg} \cdot \mathrm{kg}^{-1} \text { dry weight }\right)\right]
$$

where:

$P_{s}$ : plant-metal content originating from the soil, $S_{i}$ the total heavy metal contents in the soil.

\subsection{Daily Intake of Metals (DIM)}

Daily intake of vegetables in adult was calculated by data obtained during the survey though a questionnaire. DIM was calculated by the following equation [33]:

$$
D I M=\left[C_{\text {metal }} \times C_{\text {factor }} \times D_{\text {food int ake }}\right] / B_{\text {average weight }}
$$

$C_{\text {metai }}$ Heavy metal concentrations in plants $\left(\mathrm{mg} \cdot \mathrm{kg}^{-1}\right)$.

$C_{\text {factor }}$ Conversion factor $(\mathrm{CF})$ of 0.070 was used for the conversion of fresh vegetables to dry weight.

$D_{\text {food intake: }}$ Daily intake of the food crops was $0.50 \mathrm{~kg} \cdot$ person $^{-1} \cdot \mathrm{d}^{-1}$.

$B_{\text {average weight }}$ Body weight for the adult population was $55.0 \mathrm{~kg}$.

These values were used for the calculation of $H R I$ as well.

\subsection{Health Risk Index (HRI)}

The HRI refers to the ratio of the daily intake of metals in the food crops to the oral reference dose $(R f D)$ [32] [34] and was calculated using the following equation:

$$
H R I=D I M / R f D .
$$

An $H R I>1$ for any metal in food crops indicates that the consumer population faces a health risk.

\subsection{Microbiological Analysis}

The microbial analysis of samples was appreciate by the numeration of total mesophilic aerobic on Plate Count Agar at $37^{\circ} \mathrm{C}$ and the count recorded after 24 hours according to standard method [35].

Yeasts and moulds were enumerated on Sabouraud agar after inoculated and incubated at $30^{\circ} \mathrm{C}$ for up to 5 days according to method NF ISO21527-1 [36]. Salmonella spp. were numerated according to ISO6579 [37] at $37^{\circ} \mathrm{C} / 24 \mathrm{~h}$ on Salmonella-Shigella medium. The numeration of total coliform and fecal coliform $44^{\circ} \mathrm{C}$ on Violet Red Bill Agar (VRBG) is according to standard method ISO4832 [38].

E. coli was numerated on Eosine Methylene Blue by ISO4832 [38]. Method of NF ISO21528-2 [39] was used to enumerate Enterobacteriaceae. Staphylococcus aureus was detected by using ISO 6888-1 [40]. The counting was done by evaluating the colonies found in media [41]. Cetrimide medium was used to detect 
Pseudomonas spp. for $48 \mathrm{~h}$ at $30^{\circ} \mathrm{C}[42]$.

\subsection{Statistical Analysis}

The recorded data were subjected to two-way analysis of variance (ANOVA) to assess the influence of different variables on the concentrations of heavy metals in the vegetables tested.

ANOVA for each vegetable was performed separately using variables such as sites. All the statistical analyses were computed with STAT5 software version 8 .

\section{Results and Discussion}

\subsection{Physico-Chemical Characteristics of Wastewater}

Some of the physico-chemical properties of the wastewater are shown in Table 1. No significant difference $(\mathrm{p}>0.01)$ was found on $\mathrm{pH}$, Temperature and Dissolved oxygen. The $\mathrm{pH}$ of wastewater closed to $\mathrm{FAO}$ values and ranged from 6.58 to 6.73 respectively for Tanghin and Paspanga. Values of $\mathrm{pH}$ were lower than those of Oster and Shainberg [43] ranging from 7.29 to 7.45. They have reported that this range of irrigation water is not an acceptable criterion of water quality because it tends to be buffered by the soil, and most crops can tolerate a wide $\mathrm{pH}$ range. Temperature ranged from 25.10 to 24.90 and dissolved oxygen ranged from 3.11 to 4.67 . Conductivity and turbidity presented significant difference $(p<0.01)$ respectively from 433.00 to 561.00 and from 4.35 to 50.03 between the two sites.

\subsection{Concentration of Heavy Metal Levels in Soils Irrigated with Wastewater}

The concentration of heavy metals in the soil samples were presented in Table 2. The levels of $\mathrm{Cd}, \mathrm{Cr}, \mathrm{Cu}, \mathrm{Pb}$ and $\mathrm{Zn}$ were significantly different $(\mathrm{p}<0.01)$ in soil of the two sites. The mean values ranged of $\mathrm{Cd}$ from 3.66 to 6.60.01; $\mathrm{Cr}$, from 196.39 to $218.63 ; \mathrm{Cu}$, from 1.01 to 6.20 ; $\mathrm{Pb}$, from 20.65 to 40.26 ; $\mathrm{Zn}$, from 44.56 to $53.91 \mathrm{mg} \cdot \mathrm{kg}^{-1}$ soil, respectively for Tanghin and Paspanga. No significant ( $\mathrm{p}>$ 0.01 ) was found concern $\mathrm{Mg}$ (62.96 to $65.70 \mathrm{mg} \cdot \mathrm{kg}^{-1}$ soil) and $\mathrm{Ni}$ (15.86 to 16.18 $\mathrm{mg} \cdot \mathrm{kg}^{-1}$ soil). Excepted to Cd which were higher than standards limits values (1.5 $\left.\mathrm{mg} \cdot \mathrm{kg}^{-1}\right)$, the means values of heavy metals were lower than permissible limits

Table 1. Physico-chemical of irrigation waste water.

\begin{tabular}{|c|c|c|c|}
\hline Parameters & Site of Tanghin & Site of Paspanga & FAO standards \\
\hline $\mathrm{pH}$ & $6.58^{\mathrm{a}}$ & $6.73^{\mathrm{a}}$ & $6-8.5$ \\
\hline $\mathrm{T}^{\circ} \mathrm{C}$ & $25.10^{\mathrm{a}}$ & $24.90^{\mathrm{a}}$ & - \\
\hline Conductivity $(\mu \mathrm{S} / \mathrm{cm})$ & $433.00^{\mathrm{a}}$ & $561.00^{\mathrm{b}}$ & $0-3(\mathrm{mS} / \mathrm{cm})$ \\
\hline Turbidity (NTU) & $4.35^{\mathrm{a}}$ & $50.03^{\mathrm{b}}$ & $\mathrm{NTU}>50$ \\
\hline Dissolved oxygen $(\mathrm{mg} / \mathrm{L})$ & $3.11^{\mathrm{a}}$ & $4.67^{\mathrm{a}}$ & - \\
\hline
\end{tabular}

Values with the different letter in the same line are significantly different at $\mathrm{p}<0.01$. 
for metals $\left(\mathrm{mg} \cdot \mathrm{kg}^{-1}\right)$ in soil [44]. Also, the results obtained in this study were lower than the values reported in the soils irrigated by Uwah et al. [28]. And yet values obtained ranges exceed the permissible limits for mineral soils in arid regions [45].

The sequence of heavy metals in the soil was found in the order of $\mathrm{Cr}>\mathrm{Mn}>$ $\mathrm{Zn}>\mathrm{Pb}>\mathrm{Ni}>\mathrm{Cd}>\mathrm{Cu}$. A comparison of the data with the criterion established by Kabata-Pendias and Pendias [46] for the approximate concentrations of heavy metals in plants revealed that $\mathrm{Cr}$ was in excessive or toxic concentrations. According to Doelman [47], N mineralization and nitrification of soil were inhibited at high concentrations of heavy metals in $\mathrm{mg} \cdot \mathrm{kg}^{-1}$ around 1000 for $\mathrm{Zn}, \mathrm{Cu}$ and $\mathrm{Ni}$, around $100-500$ for $\mathrm{Pb}$ and $\mathrm{Cr}$ and around $10-100$ for $\mathrm{Cd}$. The rate of mineralization of soil organic matter appears to be sensitive to metal contamination in soil [48].

At high concentrations in soil, all heavy metals have also strong toxic effects on plants which results in weak growth, yield depression, disorders in plant metabolism and reduced nutrient uptake [12] [13]. Heavy metals not only inhibit root growth but also can hamper many physiological processes and, in particularly the uptake of nutrients [49]. The rate of absorption of elements by plants depends upon the cultivated plant and the soil properties, such as the $\mathrm{pH}$, cation exchange capacity (CEC) and distribution of metals in different soil fractions [50]. At an acidic $\mathrm{pH}$, high $\mathrm{Mn}$ concentrations in cultivated soils could pose a risk of toxicity to plant. Under an acidic $\mathrm{pH}$, free $\mathrm{Mn}$ may be the predominant form in the soil solution, making it readily available for the plants. Renella et al. [51] have reported that in Mn and Zn-polluted soils, the solubility of Mn and Zn was significantly higher in the presence of organic acids, which are typically released by plant roots, thus suggesting that plants can mobilize trace elements via their root exudates.

\subsection{Concentration of Heavy Metal Levels in Wastewater}

Concentrations of $\mathrm{Cd}, \mathrm{Cr}, \mathrm{Cu}, \mathrm{Mn}, \mathrm{Ni}, \mathrm{Pb}$ and $\mathrm{Zn}$ in different wastewater collected from Tanghin and Paspanga were given in Table 2. The sequence of heavy metals in waste water was found in the order of $\mathrm{Zn}>\mathrm{Cd}>\mathrm{Mn}>\mathrm{Pb}>\mathrm{Cu}>\mathrm{Ni}>$ Cr. Excepted Cd (2.50 to $\left.3.30 \mathrm{mg} \cdot \mathrm{L}^{-1}\right)$ and $\mathrm{Zn}\left(3.60\right.$ to $\left.3.66 \mathrm{mg} \cdot \mathrm{L}^{-1}\right)$, the samples presented significant different $(\mathrm{p}<0.01)$ of concentrations of heavy metals in the samples. The levels are varied quietly such as $\mathrm{Cr}\left(0.51\right.$ to $\left.2.27 \mathrm{mg} \cdot \mathrm{L}^{-1}\right), \mathrm{Cu}(0.88$ to $\left.3.83 \mathrm{mg} \cdot \mathrm{L}^{-1}\right), \mathrm{Mn}\left(0.29\right.$ to $\left.6.60 \mathrm{mg} \cdot \mathrm{L}^{-1}\right), \mathrm{Ni}\left(0.50\right.$ to $\left.2.30 \mathrm{mg} \cdot \mathrm{L}^{-1}\right), \mathrm{Pb}(1.37$ to $\left.3.72 \mathrm{mg} \cdot \mathrm{L}^{-1}\right)$. Excepted to $\mathrm{Pb}$ which was found to be within the acceptable safe limit, the results showed that all of the heavy metal concentrations exceeded the permissible limits in the wastewater samples set by FAO [52] as $\mathrm{Cd}\left(0.2 \mathrm{mg} \cdot \mathrm{L}^{-1}\right)$, $\mathrm{Cr}\left(0.1 \mathrm{mg} \cdot \mathrm{L}^{-1}\right), \mathrm{Cu}\left(0.2 \mathrm{mg} \cdot \mathrm{L}^{-1}\right), \mathrm{Mn}\left(0.2 \mathrm{mg} \cdot \mathrm{L}^{-1}\right), \mathrm{Ni}\left(0.2 \mathrm{mg} \cdot \mathrm{L}^{-1}\right), \mathrm{Pb}\left(5 \mathrm{mg} \cdot \mathrm{L}^{-1}\right)$ and $\mathrm{Zn}\left(2 \mathrm{mg} \cdot \mathrm{L}^{-1}\right)$. Exceeding the safe limit or having a shortage of these elements may cause diverse problems for irrigated crops according to Balkhair and Ashraf [32]. The toxic and micronutrient elements may have an inhibitory effect 
on plant growth when their concentrations exceed the safe limit. Using wastewater in irrigation for a long period may lead to an accumulation of heavy metals in agricultural soils and plants. Therefore, the use of wastewater in irrigation leads to contamination of the food chain [53].

\subsection{Concentration of Heavy Metal Levels in Lettuce Irrigated with Wastewater}

Levels of the heavy metals obtained in the vegetable samples are shown in Table

2. There is no significant difference in concentration of heavy metals between samples of Tanghin and Paspanga with the exception of Mn (0.29 to 6.60 $\left.\mathrm{mg} \cdot \mathrm{kg}^{-1}\right),(\mathrm{p}<0.01)$. Heavy metals were ranging as the concentration of $\mathrm{Cd}(1.27$ to $\left.2.93 \mathrm{mg} \cdot \mathrm{kg}^{-1}\right), \mathrm{Cr}\left(7.28\right.$ to $\left.7.38 \mathrm{mg} \cdot \mathrm{kg}^{-1}\right), \mathrm{Cu}\left(0.91\right.$ to $\left.1.70 \mathrm{mg} \cdot \mathrm{kg}^{-1}\right), \mathrm{Ni}$ (1.74 to $\left.2.16 \mathrm{mg} \cdot \mathrm{kg}^{-1}\right), \mathrm{Pb}\left(1.32\right.$ to $\left.1.69 \mathrm{mg} \cdot \mathrm{kg}^{-1}\right), \mathrm{Zn}\left(3.08\right.$ to $\left.3.79 \mathrm{mg} \cdot \mathrm{kg}^{-1}\right)$. These values were agreement with previous study of Uwah et al. [28].

The heavy metal levels in this study were also higher than the WHO maximum limit permissible (ML) in vegetables. The WHO maximum limit $\left(\mathrm{mg} \cdot \mathrm{kg}^{-1}\right)$ of some metals in vegetables are: $\mathrm{Cd}(0.02), \mathrm{Cr}(0.1-0.2), \mathrm{Cu}(0.1), \mathrm{Mn}(0.3), \mathrm{Ni}$ (0.1), $\mathrm{Pb}(0.1)$ and $\mathrm{Zn}(0.1)$ [54]. In the similar study, Shagal et al. [55] noted that Lactuca sativa grown in the same soil contained $\mathrm{Cd}, \mathrm{Cu}, \mathrm{Pb}, \mathrm{Mn}$ and $\mathrm{Zn}$ in variables concentrations.

The level of heavy metals in plants depends mainly on the levels of soil contamination and plant species [28]. The results from the present study demonstrated that plants grown on wastewater-irrigated soils are contaminated with heavy metals and pose a health concern.

In heavy metals polluted soils some plant species are able to accumulate fairly large amounts of heavy metals without showing stress, which represents a potential risk for animals and human health because of transmission in the food chain [14] [56]. Many people could be at risk of adverse health effects from consuming common vegetables grown in contaminated soils [57].

The results simply explained that the heavy metals accumulated in the soils

Table 2. Concentrations of heavy metals in the soil, wastewater and the lettuce plant.

\begin{tabular}{ccccccc}
\hline Site & \multicolumn{3}{c}{ Tanghin } & & \multicolumn{3}{c}{ Paspanga } \\
\hline $\begin{array}{c}\text { Parameters } \\
\left(\mathbf{m g} \cdot \mathbf{k g}^{-1} \text { or L }^{-1}\right)\end{array}$ & Soil & Wastewater & Lettuce & Soil & Wastewater & Lettuce \\
\hline $\mathrm{Cd}$ & $3.66 \pm 0.01^{\mathrm{a}}$ & $3.30 \pm 0.03^{\mathrm{a}}$ & $2.93 \pm 0.03^{\mathrm{a}}$ & $6.60 \pm 0.13^{\mathrm{b}}$ & $2.50 \pm 0.03^{\mathrm{a}}$ & $1.27 \pm 0.06^{\mathrm{a}}$ \\
$\mathrm{Cr}$ & $196.39 \pm 9.13^{\mathrm{a}}$ & $0.51 \pm 0.03^{\mathrm{a}}$ & $7.28 \pm 0.03^{\mathrm{a}}$ & $218.63 \pm 10.2^{\mathrm{b}}$ & $2.27 \pm 0.03^{\mathrm{b}}$ & $7.38 \pm 0.03^{\mathrm{a}}$ \\
$\mathrm{Cu}$ & $1.01 \pm 0.01^{\mathrm{a}}$ & $0.88 \pm 0.03^{\mathrm{a}}$ & $0.91 \pm 0.03^{\mathrm{a}}$ & $6.20 \pm 0.35^{\mathrm{b}}$ & $3.83 \pm 0.03^{\mathrm{b}}$ & $1.70 \pm 0.03^{\mathrm{a}}$ \\
$\mathrm{Mn}$ & $62.96 \pm 0.11^{\mathrm{a}}$ & $0.29 \pm 0.03^{\mathrm{a}}$ & $0.26 \pm 0.03^{\mathrm{a}}$ & $65.70 \pm 1.48^{\mathrm{a}}$ & $6.60 \pm 0.03^{\mathrm{b}}$ & $3.96 \pm 0.03^{\mathrm{b}}$ \\
$\mathrm{Ni}$ & $15.86 \pm 0.12^{\mathrm{a}}$ & $0.50 \pm 0.03^{\mathrm{a}}$ & $1.74 \pm 0.03^{\mathrm{a}}$ & $16.18 \pm 0.03^{\mathrm{a}}$ & $2,30 \pm 0.03^{\mathrm{b}}$ & $2.16 \pm 0.03^{\mathrm{a}}$ \\
$\mathrm{Pb}$ & $20.65 \pm 0.14^{\mathrm{a}}$ & $1.37 \pm 0.03^{\mathrm{a}}$ & $1.32 \pm 0.03^{\mathrm{a}}$ & $40.26 \pm 0.03^{\mathrm{b}}$ & $3.72 \pm 0.03^{\mathrm{b}}$ & $1.69 \pm 0.05^{\mathrm{a}}$ \\
$\mathrm{Zn}$ & $44.56 \pm 0.22^{\mathrm{a}}$ & $3.66 \pm 0.03^{\mathrm{a}}$ & $3.79 \pm 0.03^{\mathrm{a}}$ & $53.91 \pm 0.03^{\mathrm{b}}$ & $3.60 \pm 0.03^{\mathrm{a}}$ & $3.08 \pm 0.03^{\mathrm{a}}$ \\
\hline
\end{tabular}

Values with the different letter in the same line are significantly different at $\mathrm{p}<0.01$. 
are transported to the vegetables through their roots by the process of absorption. The absorption and accumulation of heavy metals in plant tissues depend upon many factors according to Rupa et al. [58].

A variation in the metal concentration may be due to the variable factors like heavy metal concentration in soil wastewater used for irrigation and atmospheric deposition along with the plant's capability to uptake and accumulate the heavy metals [58].

\subsection{Transfer Factor of Heavy Metals from Soil to Vegetables}

The results of transfer factor $(T F)$ of the heavy metals migrated from soil to lettuce of Tanghin and Paspanga sites were presented in Table 3. The $T F$ values obtained were ranging for $\mathrm{Cd}(0.19$ to 0.89$), \mathrm{Cr}(0.030$ to 0.037$), \mathrm{Cu}(0.27$ to $0.91), \mathrm{Mn}(0.004$ to 0.06$), \mathrm{Ni}(0.11$ to 0.13$), \mathrm{Pb}$ (0.04 to 0.064$), \mathrm{Zn}$ (0.057 to 0.085) respectively in the samples of Tanghin and Paspanga. Statistical test of significance using ANOVA and t-test revealed no significant difference ( $\mathrm{p}>$ 0.01 ) between the $T F$ of heavy metals migrate from soil to lettuce samples of the two sites. The results of this study revealed that the mean values of $\mathrm{Cd}(0.63)$ and $\mathrm{Cu}$ (0.72) were closed to those found (Cd: 0.64, Cu: 0.67) by Ibrahim et al. [57]. But the mean values of $T F$ of $\mathrm{Cr}$ (0.048), Mn (0.034), Ni (0.12), Pb (0.052), Zn (0.071) were lower than those reported by the same authors $(\mathrm{Cr}: 0.43, \mathrm{Cu}: 0.67$, $\mathrm{Mn}$ (0.68), Ni (0.36) Pb: 0.42, $\mathrm{Zn:} 0.71)$. The values of transfer factor of all the heavy metals in the lettuce were less than 1. According to Uwah et al. [59], it is easy for plants species with $T F>1$ to translocate metals from roots to shoots than those which restrict metals in their roots (those with TF less than1). Khan et al. [60] on the other hand, explained that if the transfer coefficient of a metal is greater than 0.50 , the plant will have a greater chance of the metal contamination by anthropogenic activities. This indicates that the levels of heavy metals in the investigated samples are low but, there is a chance for the samples of Tanghin to be contaminated with $\mathrm{Cd}(T F=0.80)$ and $\mathrm{Cu}(T F=0.91)$ by further anthropogenic activities. So the variations in transfer factors among lettuce samples in the

Table 3. Transfer factors $(T F)$ of the heavy metals from soil to lettuce.

\begin{tabular}{ccc}
\hline & \multicolumn{2}{c}{ Site } \\
\cline { 2 - 3 } Heavy metals $\left(\mathbf{m g} \cdot \mathbf{k g}^{-1}\right)$ & Tanghin & Paspanga \\
\hline $\mathrm{Cd}$ & $0.80 \pm 0.01^{\mathrm{a}}$ & $0.19 \pm 0.02^{\mathrm{a}}$ \\
$\mathrm{Cr}$ & $0.037 \pm 0.001^{\mathrm{a}}$ & $0.03 \pm 0.001^{\mathrm{a}}$ \\
$\mathrm{Cu}$ & $0.91 \pm 0.02^{\mathrm{a}}$ & $0.27 \pm 0.02^{\mathrm{a}}$ \\
$\mathrm{Mn}$ & $0.004 \pm 0.00^{\mathrm{a}}$ & $0.06 \pm 0.001^{\mathrm{a}}$ \\
$\mathrm{Ni}$ & $0.11 \pm 0.01^{\mathrm{a}}$ & $0.13 \pm 0.01^{\mathrm{a}}$ \\
$\mathrm{Pb}$ & $0.064 \pm 0.002^{\mathrm{a}}$ & $0.04 \pm 0.002^{\mathrm{a}}$ \\
$\mathrm{Zn}$ & $0.085 \pm 0.003^{\mathrm{a}}$ & $0.057 \pm 0.001^{\mathrm{a}}$
\end{tabular}

Values with the different letter in the same line are significantly different at $\mathrm{p}<0.01$. 
two studied sites may be attributed to differences in the concentration of metals in soil and differences in element uptake by different vegetables [61] [62].

Transfer factor is one of the key components of human exposure to heavy metals through the food chain. Transfer factors were computed for the heavy metals to quantify the relative differences in bioavailability of metals to vegetables or to identify the efficiency of a vegetable species to accumulate a given heavy metal [59]. Others authors as Lokeshwari and Chandrappa [11] then Awode et al. [63] demonstrated that $T F$ was based on the root uptake of the heavy metals and not the foliar absorption of atmospheric metal deposits.

\subsection{Daily Intake of Metals and Human Health Risk Assessment}

The data for the evaluation of the DIM and HRI from the heavy metal-contaminated lettuce in two sites of production were presented in Table 4. The DIM values were estimated according to the average vegetable consumption for adults and compared with the recommended daily intakes [64] [65].

The results showed that the DIM and HRI values were low in the lettuce crop. The DIM $\left(\mathrm{mg} \cdot \mathrm{kg}^{-1} \cdot\right.$ person $\left.^{-1} \cdot \mathrm{d}^{-1}\right)$ of the lettuce were ranging for $\mathrm{Cd}(0.0019$ to $0.0037), \mathrm{Cr}$ (0.0046 to 0.0047$), \mathrm{Cu}(0.00058$ to 0.0011$), \mathrm{Mn}$ (0.00016 to 0.0025$)$, $\mathrm{Ni}(0.0011$ to 0.0014$), \mathrm{Pb}(0.00084$ to 0.0011$), \mathrm{Zn}(0.00196$ to 0.0024$)$ respectively in the samples of the two sites. These results obtained were lower compared to $D I M$ values found by Umah et al. [28] respectively for $\mathrm{Cr}$ (0.012 to 0.049$), \mathrm{Ni}$ (0.0027 to 0.0052$), \mathrm{Mn}(0.0012$ to 0.016$), \mathrm{Pb}(0.018$ to 0.033$)$ and $\mathrm{Cd}(0.001$ to $0.0031)$. The $H R I$ values were lower than 1 and ranged respectively for $\mathrm{Cd}$ (0.0019 to 0.0037$), \mathrm{Cr}$ (0.0046 to 0.0047), $\mathrm{Cu}$ (0.00058 to 0.0011$), \mathrm{Mn}$ (0.00016 to $0.0025), \mathrm{Ni}(0.0011$ to 0.0014$), \mathrm{Pb}(0.00084$ to 0.0011$), \mathrm{Zn}(0.00196$ to 0.0024$)$. These values were lower comparing to those of Balkhair and Ashraf [32]. HRI< 1, but it could not exclude a possible future human health risk via the intake of lettuce coming from sites of Tanghin and Paspanga.

Table 4. Daily intakes of metals $(D I M)\left(\mathrm{mg} \cdot \mathrm{kg}^{-1} \cdot\right.$ person $\left.^{-1} \cdot \mathrm{d}^{-1}\right)$ and the Health Risk Index $(H R I)$ for individual heavy metals in lettuce irrigated with wastewater.

\begin{tabular}{|c|c|c|c|c|c|}
\hline \multirow{3}{*}{ Heavy metals } & \multirow{3}{*}{$\begin{array}{c}R f D \\
\left(\mathrm{mg} \cdot \mathrm{kg}^{-1} \mathrm{day}^{-1}\right)\end{array}$} & \multicolumn{4}{|c|}{ Risk assessment index } \\
\hline & & \multicolumn{2}{|c|}{ Tanghin } & \multicolumn{2}{|c|}{ Paspanga } \\
\hline & & $D I M$ & $H R I$ & $D I M$ & $H R I$ \\
\hline $\mathrm{Cd}$ & 0.5 & $0.0019^{\mathrm{a}}$ & $0.0037^{\mathrm{a}}$ & $0.00080^{\mathrm{a}}$ & $0.0016^{\mathrm{a}}$ \\
\hline $\mathrm{Cr}$ & 0.3 & $0.0046^{\mathrm{a}}$ & $0.015^{\mathrm{a}}$ & $0.0047^{\mathrm{a}}$ & $0.016^{\mathrm{a}}$ \\
\hline $\mathrm{Cu}$ & 0.2 & $0.00058^{\mathrm{a}}$ & $0.0029^{\mathrm{a}}$ & $0.0011^{\mathrm{a}}$ & $0.0054^{\mathrm{a}}$ \\
\hline $\mathrm{Mn}$ & 0.14 & $0.00016^{\mathrm{a}}$ & $0.0012^{\mathrm{a}}$ & $0.0025^{\mathrm{a}}$ & $0.018^{\mathrm{a}}$ \\
\hline $\mathrm{Ni}$ & 0.4 & $0.0011^{\mathrm{a}}$ & $0.0028^{\mathrm{a}}$ & $0.0014^{\mathrm{a}}$ & $0.0034^{\mathrm{a}}$ \\
\hline $\mathrm{Pb}$ & 0.6 & $0.00084^{\mathrm{a}}$ & $0.0014^{\mathrm{a}}$ & $0.0011^{\mathrm{a}}$ & $0.0017^{\mathrm{a}}$ \\
\hline $\mathrm{Zn}$ & 0.3 & $0.0024^{\mathrm{a}}$ & $0.0080^{\mathrm{a}}$ & $0.00196^{\mathrm{a}}$ & $0.0065^{\mathrm{a}}$ \\
\hline
\end{tabular}

$R f D$ : Oral reference dose $(R f D)$; Values with the different letter in the same line are significantly different at $\mathrm{p}<0.01$. 


\subsection{Microbial Quality of Fresh Lettuce}

The present study was intended to provide some assessment on the microbiological quality of lettuce and the results were assigned in Table 5. The counts of the different microorganisms enumerated were higher than the limits values of FAO/WHO [54]. The total aerobic mesophilic count (AM) ranged with significant difference $(\mathrm{p}<0.01)$ from 8.25 to $9.96 \mathrm{log} \mathrm{cfu} \cdot \mathrm{g}^{-1}$ in lettuce samples respectively from Paspanga and Tanghin. This result was higher than values of reported by Soriano et al. [66] with a range of $3.0-7.8 \mathrm{log} \mathrm{cfu} \cdot \mathrm{g}^{-1}$. According to Pianetti et al. [67], aerobic mesophilic count is useful for indicating the overall microbial quality of food product: generally it does not relate to food safety hazards but acts as an indicator for food quality and shelf-life duration.

The mean counts of total and fecal coliforms were ranged with no significant difference ( $\mathrm{p}>0.01$ ) from 5.27 to $5.77 \log \mathrm{cfu} \cdot \mathrm{g}^{-1}$ and 4.85 to $4.99 \log \mathrm{cfu} \cdot \mathrm{g}^{-1}$ from lettuce, respectively. Total coliforms were higher than those (3.3 log

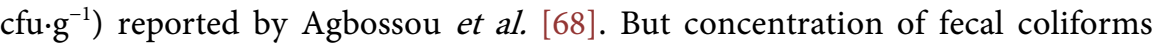
was lower comparing to $5.35 \mathrm{log} \mathrm{cfu} \cdot \mathrm{g}^{-1}$ numerated by Thiaw [69]. E. coli were detected with no significant difference ( $\mathrm{p}>0.01$ ) and ranged from 4.01 to 4.74 $\log \mathrm{cfu} \cdot \mathrm{g}^{-1}$. Salmonella spp. was reported with significant difference $(\mathrm{p}<0.01)$ in the analyzed samples ( $25 \mathrm{~g}$ of food) from to 2.07 to $3.12 \mathrm{log} \mathrm{cfu} \cdot \mathrm{g}^{-1}$ respectively for Paspanga and Tanghin.

The microflora of vegetables is diverse but consists predominantly of gram negative bacteria such as Enterobacteria. The range for this group in both samples was 3.92 to $5.48 \mathrm{log} \mathrm{cfu} \cdot \mathrm{g}^{-1}$ and presented significant difference $(\mathrm{p}<0.01)$. Agbossou et al. [69] found lower value (2 log cfu $\left.\cdot \mathrm{g}^{-1}\right)$.

The level of Enterobacteria found in this study is common in raw vegetables and are not necessarily associated with fecal contamination, because the majority of the genera are part of the endogenous microflora of the product.

Staphylococcus spp. occurred with no significant difference $(\mathrm{p}>0.01)$ respectively

Table 5. Microbial characteristics of lettuce from Tanghin and Paspanga.

\begin{tabular}{ccc}
\hline \multirow{2}{*}{ Microorganismes $\left(\log \mathrm{cfu} \cdot \mathrm{g}^{-1}\right)$} & \multicolumn{2}{c}{ Vegetable (Lettuce) } \\
\cline { 2 - 3 } Total mesophilic aerobic & Tanghin & Paspanga \\
Total coliform & $9.96^{\mathrm{a}}$ & $8.25^{\mathrm{b}}$ \\
Fecal coliform & $5.77^{\mathrm{a}}$ & $5.27^{\mathrm{a}}$ \\
E. coli & $4.85^{\mathrm{a}}$ & $4.99^{\mathrm{a}}$ \\
Salmonella spp. & $4.01^{\mathrm{a}}$ & $4.74^{\mathrm{a}}$ \\
Enterobacteria & $3.12^{\mathrm{a}}$ & $2.07^{\mathrm{b}}$ \\
Staphylococcus spp. & $5.48^{\mathrm{a}}$ & $3.92^{\mathrm{b}}$ \\
Pseudomonas spp. & $3.10^{\mathrm{a}}$ & $2.35^{\mathrm{a}}$ \\
Yeast and moulds & 0.30 & 00 \\
\hline
\end{tabular}

Values with the different letter in the same line are significantly different at $\mathrm{p}<0.01$. 
2.35 to $3.10 \log \mathrm{cfu} \cdot \mathrm{g}^{-1}$. Cesar et al. [70] assumed that Staphylococcus contamination could cause production of toxins in lettuce when count over $5 \mathrm{log} \mathrm{cfu} \cdot \mathrm{g}^{-1}$.

Pseudomonas spp. mean counted only on lettuce samples of Tanghin ( $0.30 \mathrm{log}$ $\left.\mathrm{cfu} \cdot \mathrm{g}^{-1}\right)$ and was lower those of Pianetti et al. [67] in ready-to-eat vegetables salads $\left(7 \mathrm{log} \mathrm{cfu} \cdot \mathrm{g}^{-1}\right)$. This germ is undesirable because it is often responsible for spoilage of fresh vegetables due to the production of pectinolytic enzymes which cause breakdown of the peptic polymers in plant cells [71].

Yeasts and moulds (YM) mean counts were 5.88 to $6.97 \mathrm{log} \mathrm{cfu} \cdot \mathrm{g}^{-1}$ from Paspanga and Tanghin lettuce, respectively. These means were higher those of Abadias et al. [72]. Tournas and Katsoudas [73] referred the possible health problems associated with the presence of moulds in vegetables, as some may produce mycotoxins and others are known to cause allergies when they are able to produce large numbers of conidia.

\section{Conclusions}

This study reveals that the untreated wastewater is the primary source of soil pollution, and irrigation with contaminated water containing high amounts of heavy metals and microorganisms lead to increase the concentration of metals and foodborne pathogens on the Lactuca sativa. Long-term use of wastewater as irrigation purpose may lead to severe risk to consumer's health as, this study has already shown a severe risk to human health.

The continuous monitoring of the soil, plant and water quality along with preventing metals from entering the vegetables are prerequisites for the prevention of potential health hazards to human beings.

\section{Acknowledgements}

The authors gratefully acknowledge the International Sciences Programm (ISP, Sweden) for his financial support.

\section{Conflicts of Interest}

Authors declare that we have no conflict of interest.

\section{References}

[1] Marshall, F.M. (2003) Enhancing Food Chain Integrity: Quality Assurance Mechanism for Air Pollution Impacts on Fruits and Vegetables Systems. Crop Post Harvest Program, Final Technical Report (R7530). https://assets.publishing.service.gov.uk/media/57a08cfce5274a27b2001567/R7530_F TR.pdf

[2] Radwan, M.A. and Salama, A.K. (2006) Market Basket Survey for Some Heavy Metals in Egyptian Fruits and Vegetables. Food and Chemical Toxicology, 44, 1273-1278. https://doi.org/10.1016/j.fct.2006.02.004

[3] Khan, M.J., Drochner, W., Steingass, H. and Islam, K.M.S. (2008) Nutritive Evaluation of Some Tree Leaves from Bangladesh for Feeding Ruminant Animals. Indian Journal of Animal Science, 78, 1273-1277. 
http://epubs.icar.org.in/ejournal/index.php/IJAnS/article/view/4991/2097

[4] Maleki, A. and Zarasvand, M.A. (2008) Heavy Metals in Selected Edible Vegetables and Estimation of Their Daily Intake in Sanandaj, Iran. The Southeast Asian Journal of Tropical Medicine and Public Health, 39, 335-340.

[5] Wong, C.S.C., Li, X.D., Zhang, G., Qi, S.H. and Peng, X.Z. (2003) Atmospheric Depositions of Heavy Metals in the Pearl River Delta, China. Atmospheric Environment, 37, 767-776. https://doi.org/10.1016/S1352-2310(02)00929-9

[6] Sharma, R.K., Agrawal, M. and Marshall, F.M. (2008) Heavy Metals (Cu, Cd, Zn and $\mathrm{Pb}$ ) Contamination of Vegetables in Urban India: A Case Study in Varanasi. Environmental Pollution, 154, 254-263. https://doi.org/10.1016/j.envpol.2007.10.010

[7] FAOSTAT (2016) Situation of Tomato Production in Burkina Faso. http://www.fao.org/faostat/fr/\#data/QC

[8] Cisse, G., Kientga, M., Ouedraogo, B. and Tanner, M. (2002) Development of Market Gardening around Dams in Ouagadougou: What Are the Health Risks to Be Taken into Account? Agricultural Notebook, 11, 31-38. http://revues.cirad.fr/index.php/cahiers-agricultures/article/viewFile/30327/30087

[9] Mashiatullah, A., Riffat, M., Qureshi, A., Niaz, T., Javed, J. and Nisar, A. (2005) Biological Quality of Ground Water in Rawalpindi/Islamabad. The Environ. Monitor, 5, 13-18.

$\underline{\text { https://scholar.google.com/scholar?hl=en\&as_sdt=0,5\&cluster }=13420672379639080}$ $\underline{186}$

[10] Mougeot, L.J.A. (2006) Urban Agriculture and Sustainable Development. IV. Coll.: Focus (International Development Research Center), 137 p. https://idl-bnc-idrc.dspacedirect.org/handle/10625/30554

[11] Lokeshwari, H. and Chandrappa, G.T. (2006) Impact of Heavy Metal Contamination of Bellandur Lake on Soil and Cultivated Vegetation. Current Science, 91, 622-627. https://www.jstor.org/stable/24094365

[12] Broos, K., Beyens, H. and Smolders, E. (2005) Survival of Rhizobia in Soil Is Sensitive to Elevated Zinc in the Absence of the Host Plant. Soil Biology Biochemical, 37, 573-579. https://doi.org/10.1016/j.soilbio.2004.08.018

[13] Dan, T., Hale, B., Johnson, D., Conard, B., Stiebel, B. and Veska, E. (2008) Toxicity Thresholds for Oat (Avena sativa L.) Grown in Ni-Impacted Agricultural Soils near Port Colborne, Ontario, Canada. Canadian Journal Soil Science, 88, 389-398. https://doi.org/10.4141/CJSS07070

[14] Gincchio, R., Rodriguez, P.H., Badilla-Ohlbaum, R., Allen, H.E. and Lagos, G.E. (2002) Effect of Soil Copper Content and pH on Copper Uptake of Selected Vegetables Grown under Controlled Conditions. Environmental Toxicology and Chemistry, 21, 1736-1744. https://doi.org/10.1002/etc.5620210828

[15] Friesl, W., Friedl, J., Platzer, K., Horak, O. and Gerzabek, M.H., (2006) Remediation of Contaminated. Agricultural Soils near a Former $\mathrm{Pb} / \mathrm{Zn}$ Smelter in Austria: Batch, Pot and Field Experiments. Pollution, 144, 40-50. https://doi.org/10.1016/j.envpol.2006.01.012

[16] Cambra, K., Martinez, T., Urzelai, A. and Alonsa, E. (1999) Risk Analysis of a Farm Area near a Lead- and Cadmium-Contaminated Industrial Site. Journal Soil Contamination, 8, 527-540. https://doi.org/10.1080/10588339991339450

[17] Dudka, S. and Miller, W.P. (1999) Permissible Concentrations of Arsenic and Lead in Soils Based on Risk Assessment. Water and Soil Pollution, 113, 127-132. https://doi.org/10.1023/A:1005028905396 
[18] Suruchi and Khanna, P. (2011) Assessment of Heavy Metal Contamination in Different Vegetables Grown in and around Urban Areas. Research Journal of Environmental Toxicology, 5, 162-179. https://doi.org/10.3923/rjet.2011.162.179

[19] Dauguet, S., Denaix, L., Nguyen, C., Royer, E., Levasseur, P., Potin-Gautier, M., Lespes, G., Parat, C., Héroult, J., Coudure, R., Chéry, P., Devert, M., Robert, N. and Pouech, P. (2011) Measurement of Trace Element Fluxes (Pb, Cd, As, Cu, Zn) in Soils, Plants, Pigs and Manure from Southwest Hog Farms. Agronomic Innovations, 17, 175-190.

https://www6.inra.fr/ciag/content/download/3731/35925/file/Vol17-13-Dauget.pdf

[20] Miquel, G. (2001) Information Report No. 261. Parliamentary Office on the Evaluation of Scientific and Technological Choices, $344 \mathrm{p}$. http://www.senat.fr/rap/100-261/100-261.html

[21] Den, H., Ye, Z.H. and Wong, M.H. (2004) Accumulation of Lead, Zinc, Copper and Camium by 12 Wetland Plant Species Thriving in Metal Contaminated Sites China. Environmental Pollution, 29, 40-132.

[22] Hani, A., Pazira, E., Manshouri, M., Kafaky, S.B. and Tali, M.G. (2010) Spatial Distribution and Mapping of Risk Elements Pollution in Agricultural Soils of Southern Tehran, Iran. Plant Soil Environment, 56, 288-296. https://www.agriculturejournals.cz/publicFiles/16_2010-PSE.pdf https://doi.org/10.17221/16/2010-PSE

[23] Stagnitti, F., Sherwood, J., Allinson, G., Evans, L., Allinson, M., Li, L. and Phillips, I. (1998) An Investigation of Localized Soil Heterogeneities on Solute Transport Using a Multisegement Percolation System. New Zealand Journal of Agricultural Research, 41, 603-612. https://doi.org/10.1080/00288233.1998.9513344

[24] Stagnitti, F. (1999) A Model of the Effects of Nonuniform Soil-Water Distribution on the Subsurface Migration of Bacteria: Implications for Land Disposal of Sewage. Mathematical and Computer Modelling, 29, 41-52. https://doi.org/10.1016/S0895-7177(99)00038-2

[25] Keraita, B., Drechsel, P.F., Huibers, P. and Raschid-Sally, L. (2002) Wastewater Use in Informal Irrigation in Urban and Periurban Areas of Kumasi, Ghana. Urban Agriculture Magazine, 8, 11-13.

[26] Cui, Y.J., Zhu, Y.G., Zhai, R., Huang, Y., Qiu, Y. and Liang, J. (2005) Exposure to Metal Mixtures and Human Health Impacts in a Contaminated Area in Nanning, China. Environm International, 31, 784-790. https://doi.org/10.1016/j.envint.2005.05.025

[27] Bi, X., Feng, X., Yang, Y., Qiu, G., Li, G., Li, F., Liu, T., Fu, Z. and Jin, Z. (2006) Environmental Contamination of Heavy Metals from Zinc Smelting Areas in Hezhang County, Western Guizhou, China. Environment International, 32, 883-890. https://doi.org/10.1016/j.envint.2006.05.010

[28] Uwah, E.I., Gimba, M.S.B. and Gwaski, P.A. (2012) Determination of Zn, Mn, Fe and $\mathrm{Cu}$ in Spinach and Lettuce Cultivated in Potiskum, Yobe State, Nigeria. Journal of Agricultural Economics and Development, 1, 69-74. http://www.academeresearchjournals.org/print.php?id=509cde8f56d25

[29] Musa, A.I. and Parmeshwal, L. (2018) Analysis of Heavy Metals and Minerals in Fruit Juices by Inductively Coupled Plasma Mass Spectrometry Coupled with Atomic Absorption Spectroscopy. International Journal of Recent Scientific Research, 9, 25509-25511.

[30] APHA (2005) Standard Methods for the Examination of Water and Wastewater. APH Association, Washington DC. 
[31] Li, M.H., Robinson, E.H., Oberle, D.F., Lucas, P.M. and Bosworth, B.G. (2012) Evaluation of Corn Gluten Feed and Cottonseed Meal as Partial Replacements for Soybean Meal and Corn in Diets for Pond-Raised Hybrid Catfish, Ictalurus punctatus, I. furcatus. Journal of the World Aquaculture Society, 43, 107-113.

[32] Balkhair, K.S. and Ashraf, M.A. (2016) Field Accumulation Risks of Heavy Metals in Soil and Vegetable Crop Irrigated with Sewage Water in Western Region of Saudi Arabia Saudi. Journal of Biological Sciences, 23, S32-S44. https://doi.org/10.1016/j.sjbs.2015.09.023

[33] Chary, N.S., Kamala, C.T. and Raj, D.S.S. (2008) Assessing Risk of Heavy Metals from Consuming Food Grown on Sewage Irrigated Soils and Food Chain Transfer. Ecotoxicology Environment Safety, 69, 513-524. https://doi.org/10.1016/j.ecoenv.2007.04.013

[34] EPA U. (2002) United State, Environmental Protection Agency, Region 9, Preliminary Remediation Goals. https://semspub.epa.gov/work/02/103453.pdf

[35] ISO4833-1 (2013) Microbiology of the Food Chain-Horizontal Method for the Enumeration of Microorganisms. International Organization for Standardization. https://www.boutique.afnor.org/resources/28167a60-b20a-47a9-b620-ec8823348a5e .pdf

[36] NF ISO21527-1:V08-040-1 (2008) Microbiology of Food-Horizontal Method for the Enumeration of Yeasts and Molds. Part 1: Colony Count Technique in Products with Water Activity Greater than 0.95 .

https://www.boutique.afnor.org/resources/28167a60-b20a-47a9-b620-ec8823348a5e .pdf

[37] NF EN ISO6579:V08-013 (2002) Microbiology of Food and Animal Feeding Stuffs-Horizontal Method for the Detection of Salmonella.

https://www.boutique.afnor.org/resources/28167a60-b20a-47a9-b620-ec8823348a5e .pdf

[38] ISO4832 (2006) Microbiology of Food and Animal Feeding Stuffs-Horizontal Method for the Enumeration of Coliforms-Colony-Count Technique. International Organization for Standardization, Geneva.

https://www.boutique.afnor.org/resources/28167a60-b20a-47a9-b620-ec8823348a5e . $\mathrm{pdf}$

[39] NF ISO21528-2:V08-039 (2004) Microbiology of food-Horizontal methods for the detection and enumeration of Enterobacteriaceae. Part 2: colony count method. https://www.boutique.afnor.org/resources/28167a60-b20a-47a9-b620-ec8823348a5e .pdf.

[40] ISO6888-1 (1999) Microbiology of Food and Animal Feeding Stuffs-Horizontal Method for Enumeration of Coagulase-Positive Staphylococci (Staphylococcus aureus and Other Species). International Organization for Standardization. https://www.boutique.afnor.org/resources/28167a60-b20a-47a9-b620-ec8823348a5e .pdf

[41] Holzapfel, W.H., Haberer, P., Geisen, R., Björkroth, J. and Schillinger, U. (2001) Taxonomy and Important Features of Probiotic Microorganisms in Food and $\mathrm{Nu}$ trition. American Journal Clinical Nutrition, 73, 365S-73S.

[42] NFV04-504 (2006) Microbiology of Foods. Enumeration of Pseudomonas Sin Meat and Meat Products and Poultry-Routine Method.

https://www.boutique.afnor.org/resources/28167a60-b20a-47a9-b620-ec8823348a5e .pdf

[43] Shainberg, I. and Oster, J.D. (1978) Quality of Irrigation Water. Vol. 2, Internation- 
al Irrigation Information Center, IIIC, 61-65.

https://books.google.bf/books?isbn=008023822X

[44] Ghorbani, N.R., Salehrastin, N. and Moeini, A. (2002) Heavy Metals Affect the Microbial Populations and Their Activities. Symposium No. 54 at 17 th World Congress of Soil Science, 14-21 August 2002, Vol. 2234, 1-11.

http://citeseerx.ist.psu.edu/viewdoc/download?doi=10.1.1.4.4743\&rep=rep1\&type $=$ pdf

[45] Brady, N.C. and Weil, R.R. (1996) The Nature and Properties of Soils. Prentice Hall Inc., Upper Saddle River.

[46] Kabata-Pendias, A. and Pendias, H. (2001) Trace Elements in Soils and Plants. 3rd Edition, CRC Press, Boca Raton, 321-337.

[47] Doelman, P., Jansen, E., Michels, M. and Van-Til, M. (1994) Effects of Heavy Metals in Soil on Microbial Diversity and Activity as Shown by the Sensitivity Resistance Index. Biological Fertility Soils, 17, 177-184. https://doi.org/10.1007/BF00336319

[48] Baath, E. (1992) Effect of Heavy Metals in Soil on Microbial Process and Population. Water, Air and Pollution, 47, 335-379. https://doi.org/10.1007/BF00279331

[49] Asp, H., Gussarsson, M., Adalsteinsson, S. and Jensen, P. (1994) Control of Potassium Influx in Roots of Birch (Betula pendula) Seedlings Exposed to Cadmium. Journal Experimental Botany, 45, 1823-1827. https://doi.org/10.1093/jxb/45.12.1823

[50] Kos B., Suskovic, J., Vukovic, S., impraga, M.S., Frece, J. and Matosic, S. (2003) Adhesion and Aggregation Ability of Probiotic Strain Lactobacillus acidophilus M92. Journal of Applied Microbiology, 94, 981-987. https://doi.org/10.1046/j.1365-2672.2003.01915.x

[51] Renella, G., Mench, M., van der Lelie, D., Pietramellara, G., Ascher, J., Ceccherini, M.T., Landi, L. and Nannipieri, P. (2004) Microbial Activity and Hydrolase Synthesis in Long-Term Cd-Contaminated Soils. Soil Biology Biochemistry, 36, 443-451. https://doi.org/10.1016/j.soilbio.2003.10.022

[52] FAO (1985) Water Quality for Agriculture. FAO Irrigation and Drainage Paper No. 29, Rome, FAO, Rome. http://www.fao.org/docrep/003/T0234E/T0234E00.htm

[53] Muchuweti, M., Birkett, J.W., Chinyanga, E., Zvauya, R., Scrimshaw, M.D. and Lester, J.N. (2006) Heavy Metal Content of Vegetables Irrigated with Mixtures of Wastewater and Sewage Sludge in Zimbabwe: Implications for Human Health. Agriculture, Ecosystems Environment, 112, 41-48. https://doi.org/10.1016/j.agee.2005.04.028

[54] FAO/WHO Codex Alimentarius Commission (2001) Food Additives and Contaminants. Joint FAO/WHO Food Standards Programme; ALINORM 01/12A, 1-289. http://www.fao.org/3/a-x8723e.pdf

[55] Shagal, M.H., Maina, H.M., Donatus, R.B. and Tadzabia, K. (2012) Bioaccumulation of Trace Metals Concentration in Some Vegetables Grown near Refuse and Effluent Dumpsites along Rumude-Doubeli Bye-Pass in Yola North, Adamawa State. Global Advanced Research Journal of Environmental Science and Toxicology, 1, 18-22. http://garj.org/garjest/index.htm

[56] Oliver, M.A. (1997) Soil and Human Health: A Review. European Journal of Soil Science, 48, 573-592. https://doi.org/10.1046/j.1365-2389.1997.00124.x

[57] Ibrahim, A.K., Yakubu, H. and Askira, M.S. (2014) Assessment of Heavy Metals Accumulated in Wastewater Irrigated Soils and Lettuce (Lactuca sativa) in Kwadon, Gombe State Nigeria. American-Eurasian Journal of Agricultural \& Environmental Sciences, 14, 502-508. 
[58] Rupa, T.R., Srinivasa Rao, C., Subba Rao, A. and Singh, M. (2003) Effects of Farmyard Manure and Phosphorus on Zinc Transformations and Phyto-Availability in Two Alfisols of India. Bioresource Technology, 87, 279-288. https://doi.org/10.1016/S0960-8524(02)00235-3

[59] Uwah, D.F., Undie, U.L. and John, N.M. (2014) Comparative Evaluation of Animal Manures on Soil Properties, Growth and Yield of Sweet Maize (Zea mays L. saccharata Strut.). Journal of Agriculture and Environmental Sciences, 3, 315-333. http://jaesnet.com/journals/jaes/Vol_3_No_2_June_2014/20.pdf

[60] Khan, S., Farooq, R., Shahbaz, S., Khan, M.A. and Sadique, M. (2009) Health Risk Assessment of Heavy Metals for Population via Consumption of Vegetables. World Applied Sciences Journal, 6, 1602-1606.

https://kenanaonline.com/files/0071/71999/health\%20risk\%20assessment\%20of\%20 heavy\%20metals\%20for\%20population\%20via\%20consumption\%20of\%20vegetable s.pdf

[61] Cobb, G.P.K., Sands, M., Waters, B.G., Wixson, W. and Doward-King, D. (2000) Accumulation of Heavy Metals by Vegetables Grown in Mine Waste. Environmental Toxicology Chemistry, 19, 600-607. https://doi.org/10.1002/etc.5620190311

[62] Cui, Y.J., Zhu, Y.G., Zhai, R.H., Chen, D.Y., Huang, Y.Z., Qui, Y. and Liang, J.Z. (2004) Transfer of Metals from near a Smelter in Nanniang, China. Environment International, 30, 785-791. https://doi.org/10.1016/j.envint.2004.01.003

[63] Awode, U.A., Uzairu, A., Balarabe, M.L., Okunola, O.J. and Adewusi, S.G. (2008) Levels of Some Trace Metals in the Fadama Soils and Pepper (Capsicum annuum) along the Bank of River Challawa, Nigeria. Asian Journal Science Research, 1454, 1-6. https://doi.org/10.3923/ajsr.2008.458.463

[64] WHO (1996) Guidelines for Drinking-Water Quality, Vol. 2, Health Criteria and Other Supporting Information. World Health Organization, Geneva. https://apps.who.int/iris/handle/10665/38551

[65] Trumbo, P., Yates, A.A., Schlicker, S. and Poos, M. (2001) Dietary Reference Intakes: Vitamin A, Vitamin K, Arsenic, Boron, Chromium, Copper, Iodine, Iron, Manganese, Molybdenum, Nickel, Silicon, Vanadium, and Zinc. Journal of the American Dietetic Association, 101, 294-301. https://doi.org/10.1016/S0002-8223(01)00078-5

[66] Soriano, J., Rico, M.H., Molto, J.C. and Manes, J. (2000) Assessment of the Microbiological Quality and Wash Treatments of Lettuce Served in University Restaurants. International Journal of Food Microbiology, 58, 123-128. https://doi.org/10.1016/S0168-1605(00)00288-9

[67] Pianetti, A., Sabatini, L., Citterio, B., Pierfelici, L., Ninfali, P. and Bruscolini, F. (2008) Changes in Microbial Populations in Ready-to-Eat Vegetable Salads during Shelf-Life. Italian Journal of Food Science, 20, 245-254.

[68] Agbossou, K.E., Sanny, M.S., Zokpodo, B., Ahamide, B. and Guedegbe, H.J. (2003) Evaluation quantitative de quelques légumes sur le périmètre maraîcher de Houéyiho, à Cotonou au sud-Bénin. Bulletin de la recherche agronomique du Benin, 42 p. http://www.slire.net/document/1150

[69] Thiaw, K. (2006) La qualité sanitaire des produits maraîchers de la ville de Ouagadougou: Incidence de la source d'eau d'irrigation sur la santé humaine. Groupe des écoles, Ouagadougou. http://documentation.2ie-edu.org/cdi2ie/opac_css/doc_num.php?explnum_id=748

[70] Cesar, J.G., Peres, A.M., Pereira das Neves, C., Freitas de Abreu, E.T., Fagundes de Mello, J., Moreira, A.N. and Rodrigues, K.L. (2015) Microbiological Assessment of 
Lettuce Salads and Antimicrobial Resistance of Staphylococcus spp. Nutricion hospitalaria: Organo oficial de la Sociedad Espanola de Nutricion Parenteral y Enteral, 32, 2280-2285.

[71] Membre, J.M. and Burlot, P.M. (1994) Effects of Temperature, $\mathrm{pH}$, and $\mathrm{NaCl}$ on Growth and Pectinolytic Activity of Pseudomonas marginalis. Applied and Environmental Microbiology, 60, 2017-2022.

https://aem.asm.org/content/aem/60/6/2017.full.pdf

[72] Abadias, M., Usall, J., Anguera, M., Solsona, C. and Vinas, I. (2008) Microbiology Quality of Fresh, Minimally-Processed Fruit and Vegetables, and Sprouts from Retail Establishments. International Journal of Food Microbiology, 123, 121-129.

https://doi.org/10.1016/j.ijfoodmicro.2007.12.013

[73] Tournas, V.H. and Katsoudas, E. (2005) Mould and Yeast Flora in Fresh Berries, Grapes and Citrus Juices. International Journal of Food Microbiology, 105, 11-17. https://doi.org/10.1016/j.ijfoodmicro.2005.05.002 